\title{
Estudo da Influência de Tratamentos Químicos da Fibra de Sisal nas Propriedades de Compósitos com Borracha Nitrílica
}

\author{
Marco A. Iozzi, Gilson S. Martins \\ Interunidades em Ciência e Engenharia de Materiais EESC/IFSC/IQSC - USP \\ 3M do Brasil Ltda \\ Maria A. Martins \\ Universidade Federal do $A B C$ \\ Fábio C. Ferreira \\ Faculdades Adamantinenses Integradas \\ Aldo E. Job \\ Departamento de Física, Química e Biologia - UNESP \\ Luiz H. C. Mattoso \\ Embrapa Instrumentação Agropecuária
}

\begin{abstract}
Resumo: A influência de diferentes tratamentos das fibras de sisal nas propriedades dos compósitos de borracha nitrílica/ fibras de sisal, e borracha nitrílica/carbonato de cálcio/fibras de sisal foi investigada. Os compósitos, com fibras curtas aleatoriamente distribuídas, foram processados em moinho de dois rolos e caracterizados através de ensaios mecânicos de resistência à tração, microscopia eletrônica de varredura (MEV), análise por termogravimetria (TG) e calorimetria exploratória diferencial (DSC). O tratamento de mercerização das fibras levou a uma maior adesão na interface fibra/matriz. O uso combinado de 67 pcr de carbonato com 33 pcr de fibras de sisal mercerizadas produziu um compósito com aumento significativo no módulo de elasticidade e sem perda da resistência à tração de ruptura. Os resultados da análise térmica mostraram que os compósitos são termicamente estáveis até cerca de $300{ }^{\circ} \mathrm{C}$. Os materiais obtidos possuem uma boa relação custo/benefício tornando promissora sua utilização.
\end{abstract}

Palavras-chave: Borracha nitrílica, fibra natural, compósito.

\section{Study of the Influence from Chemical Treatments of Sisal Fibers on the Properties of Composites with Nitrile Rubber}

Abstract: In this work, composites were produced with nitrile rubber and sisal fibers, and nitrile rubber with calcium carbonate and sisal fibers. The composites were processed on a two-roll mixing mill and their properties were investigated with regard to the influence of chemical treatments of the fibers. The composites, with short fibers randomly distributed, were characterized by mechanical analysis, scanning electron microscopy (SEM), thermogravimetric analysis (TGA) and differential scanning calorimetry (DSC). Mercerization treatment of the fibers promoted increasing the adhesion between the fiber and the rubber matrix. The composites of nitrile rubber with $67 \mathrm{pcr}$ of calcium carbonate and $33 \mathrm{pcr}$ of mercerized sisal fibers showed the best mechanical properties. Thermal analysis demonstrated that the composites are thermally stable up to $300{ }^{\circ} \mathrm{C}$. The materials developed have a good cost/benefit relationship making their utilization promising.

Keywords: Nitrile rubber, natural fiber, composite.

\section{Introdução}

Sendo uma fonte renovável, reciclável, biodegradável e de baixo custo, o uso de recursos vegetais para a produção de compósitos poliméricos consiste numa alternativa de grande importância tecnológica. Para países com forte economia agrícola como o Brasil, o uso de fibras naturais como fonte de matéria-prima para a indústria de polímeros reforçados, é uma forma importante de ampliar as possibilidades de explorar suas fontes de matérias-primas naturais com agregação de valor ${ }^{[1,2]}$.

Autor para correspondência: Luiz H. C. Mattoso, Embrapa Instrumentação Agropecuária, Rua XV de Novembro 1452, Caixa Postal 741, CEP: 13560-970,

São Carlos, SP, Brasil. E-mail: mattoso@cnpdia.embrapa.br 
A importância dos compósitos em engenharia deriva do fato de que, ao combinar-se dois ou mais materiais diferentes, pode-se obter um material compósito cujas propriedades são superiores, ou melhores, em alguns aspectos, às propriedades de cada um dos componentes. Os materiais compósitos podem ser selecionados para dar combinações não usuais de propriedades não existentes em um único material, como resistência mecânica, tenacidade, peso, dureza, condutividade, resistência à corrosão, desempenho em altas temperaturas, dentre outras ${ }^{[3,4]}$. Os polímeros nitrílicos são amorfos, não cristalinos, e necessitam de cargas de reforço para que suas propriedades sejam otimizadas ${ }^{[5,6]}$. O sistema borracha/reforço, como borracha/cargas inorgânicas ${ }^{[7-9]}$, e no caso especial borracha/fibras, podem ser considerados compósitos que combinam a resistência e rigidez do reforço com o comportamento elástico da borracha ${ }^{[10]}$.

Entretanto, uma limitação ao uso de fibras naturais como reforços em matrizes termoplásticas, de modo a obterem-se materiais compósitos com propriedades mecânicas e estabilidade dimensional melhoradas, é a pequena molhabilidade e a fraca ligação interfacial com o polímero, devido a pouca compatibilidade entre as fibras celulósicas hidrofílicas com os termoplásticos hidrofóbicos ${ }^{[11]}$. O desempenho de compósitos reforçados com fibras, além das características da fibra, também depende da compatibilização entre a fibra e a matriz de borracha ${ }^{[12]}$. A interface fibra/matriz é a região onde ocorre o contato entre os componentes do compósito. A região interfacial é a principal responsável pela transferência da solicitação mecânica da matriz para o reforço. A adesão inadequada entre as fases envolvidas na interface poderá provocar o início de falhas, comprometendo o desempenho do compósito. Portanto, além das propriedades individuais de cada componente do compósito, a interface deve ser a mais adequada possível para otimizar a combinação das propriedades envolvidas ${ }^{[1,12]}$.

Métodos físicos e químicos podem ser usados para modificar as fibras de reforço, otimizando a interface fibra-matriz. A literatura relata diversos estudos onde as propriedades físico-químicas e a modificação da superfície das fibras vegetais são investigadas, objetivando sua utilização em materiais compósitos ${ }^{[1,11-17]}$.

Entre as fibras vegetais produzidas no Brasil, as fibras de sisal se destacam pelas suas características físico-químicas e propriedades mecânicas. Esta fibra está entre as fibras vegetais mais utilizadas mundialmente. Quimicamente, as fibras vegetais consistem de celulose, hemicelulose, lignina e uma pequena quantidade de ceras e gorduras ${ }^{[6,11,16,18]}$.

O objetivo deste trabalho foi estudar a influência de diferentes tratamentose teores dafibra de sisal nas propriedades mecânicas de compósitos de borracha nitrílica/sisal com e sem a adição de carbonato de cálcio. Os compósitos foram caracterizados através de ensaios mecânicos de resistência à tração, microscopia eletrônica de varredura (MEV), análise por termogravimetria (TG) e calorimetria exploratória diferencial (DSC).

\section{Experimental}

\section{Materiais}

As fibras de sisal (variedade Agave sisalana), são provenientes de Campina Grande/PB. As amostras foram extraídas de plantas no segundo ano de colheita, e possuíam $1,50 \mathrm{~m}$ de comprimento, sendo fornecidas pela Embrapa/ CNPA.

A borracha nitrílica utilizada foi a Nitriflex ${ }^{\circledR} \mathrm{N}-206$, produzida pela Nitriflex S/A, preparada com um teor de acrilonitrila de $45 \%$, massa específica de $0,98 \mathrm{~g} / \mathrm{cm}^{3}$ e viscosidade Mooney de 50 - 70 (ML 4' a $100{ }^{\circ} \mathrm{C}$ ). Utilizou-se como estabilizante o produto "Santowhite ${ }^{\circledast}$ crystals", produzido pela empresa Monsanto, indicado pelo fabricante da borracha e fornecido pela $3 \mathrm{M}$ do Brasil Ltda.

O carbonato de cálcio usado foi o produzido pela empresa Beneficiadora de Minerais Curuçá Ltda, com massa específica de $2,50 \mathrm{~g} / \mathrm{cm}^{3}$, estrutura cristalina romboédrica, tendo $40 \%$ das partículas abaixo de $5 \mu \mathrm{m}$.

\section{Métodos}

Amostras de fibra de sisal foram submetidas a quatro tratamentos descritos abaixo:

1) Lavagem com água a $80^{\circ} \mathrm{C}$, por 1 hora;

2) Lavagem com solução de detergente neutro Extran a $20 \%$, por um período de 1 horas, a $80 \pm 2{ }^{\circ} \mathrm{C}$;

3) Tratamento com solução acetona/água $(1: 1, \mathrm{v} / \mathrm{v})$ por 2 horas, à temperatura ambiente; $\mathrm{e}$

4) Tratamento de mercerização em solução de $10 \%$ hidróxido de sódio $(\mathrm{NaOH})$, por períodos de 3, 5 e 10 horas, à temperatura ambiente. Após os tratamentos as fibras foram neutralizadas com sucessivas lavagens em água, e secas em estufas por um período de 6 horas, à temperatura de $80^{\circ} \mathrm{C}$.

Para o estudo da influência do tratamento das fibras de sisal nas propriedades mecânicas de compósitos com a borracha nitrílica foram utilizadas as fibras sem tratamentos, as lavadas com água e as mercerizadas por 3 horas. O teor de antioxidante e de fibra foi mantido constante em todos os casos em 1 pcr e 22 pcr (partes por cem partes de resina), respectivamente. $O$ teor de carbonato de cálcio de 33 e 67 pcr, e o comprimento das fibras, $6 \mathrm{~mm}$, foram estabelecidos em estudos anteriores ${ }^{[6]}$.

Avaliou-se também a influência de diferentes teores das fibras $(0 ; 5,5 ; 11 ; 22 ; 33$ e 44 pcr $)$ nas propriedades dos compósitos. Para este estudo foi utilizada a fibra mercerizada (solução de $\mathrm{NaOH}$ a 10\%, 3 horas, à temperatura ambiente), com comprimento igual a $6 \mathrm{~mm}$. O teor de antioxidante e de carbonato de cálcio foi mantido constante em todos os casos em 1 pcr e 67 pcr, respectivamente.

Os compósitos foram processados em uma calandra Mecanoplast modelo C-400-2S. Todas as amostras foram processadas à temperatura de $130 \pm 5{ }^{\circ} \mathrm{C}$ e o tempo total para processamento foi estabelecido em 20 minutos: 5 minutos para 
mastigação da borracha, massa igual a 200 g, e incorporação do estabilizante; 5 minutos para incorporação do carbonato de cálcio; 5 minutos para incorporação das fibras de sisal; e 5 minutos para homogeneização da massa. As amostras sem carbonato em sua composição tinham 5 minutos para adição deste componente incorporados ao tempo de mastigação da borracha. A adição das fibras de sisal foi feita na última etapa para minimizar as quebras durante o processamento. Neste processamento não foi realizada a etapa de vulcanização da borracha.

Os ensaios de resistência à tração foram realizados em uma Máquina de Ensaio Universal - EMIC DL 500 MF, segundo a norma ASTM D 412-98, método A, com as seguintes condições: abertura entre garras de $50 \mathrm{~mm}$, velocidade de deslocamento das garras igual a $500 \mathrm{~mm} / \mathrm{min}$, célula de carga de $100 \mathrm{~N}$.

As análises por termogravimetria (TG) foram realizadas em um equipamento NETZSCH modelo TG 209, com início à temperatura ambiente até $600{ }^{\circ} \mathrm{C}$, com uma razão de aquecimento de $10{ }^{\circ} \mathrm{C} / \mathrm{min}$, usando nitrogênio como gás de arraste, com fluxo de $15 \mathrm{~mL} / \mathrm{min}$.

Os ensaios de DSC foram realizados em um instrumento NETZSCH modelo DSC 204, em uma faixa de temperatura de $-100{ }^{\circ} \mathrm{C}$ a $400{ }^{\circ} \mathrm{C}$, com uma razão de aquecimento de $10^{\circ} \mathrm{C} / \mathrm{min}$, usando nitrogênio como gás de arraste, com fluxo de $30 \mathrm{~mL} / \mathrm{min}$.

Para a caracterização por microscopia eletrônica de varredura (MEV) utilizou-se um microscópio eletrônico marca ZEISS modelo DSM 960, com um feixe de elétrons de $20 \mathrm{kV}$. Sobre as amostras foi depositada uma camada de ouro, usando um "sputter coater" (plasma de argônio) marca BALZERS modelo SCD 50.

\section{Resultados e Discussão}

A primeira etapa do trabalho foi a investigação por MEV do efeito dos tratamentos na morfologia da fibra de sisal. Micrografias representativas de uma fibra sem tratamento, de uma lavada com o detergente e uma após a lavagem com a solução água/acetona são mostradas na Figura 1. Observou-se que a superfície da fibra sem tratamento é recoberta pelas células de parênquima, bem como por impurezas e resíduos provenientes do processo de beneficiamento e do manuseio, Figura 1a. Diversos estudos ${ }^{[19-21]}$ relatam que os resíduos presentes na superfície das fibras vegetais diminuem a adesão, quando estas fibras são utilizadas em materiais compósitos, e por isto, vários tratamentos estão sendo realizados com o objetivo de melhorar as propriedades superficiais das fibras. No nosso trabalho, observou-se que tanto a lavagem com detergente quanto a com solução água/acetona removeram grande parte das impurezas presentes na superfície da fibra e que as células de parênquima foram parcialmente removidas. Em trabalho anterior ${ }^{[6]}$, o efeito da lavagem com água sobre a superfície da fibra de sisal foi analisado, observou-se que as mudanças morfológicas ocorridas na superfície das fibras

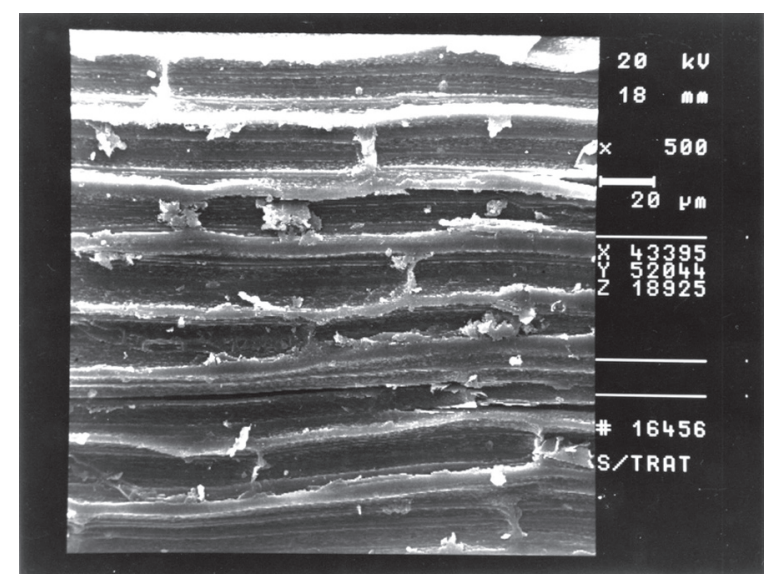

(a)

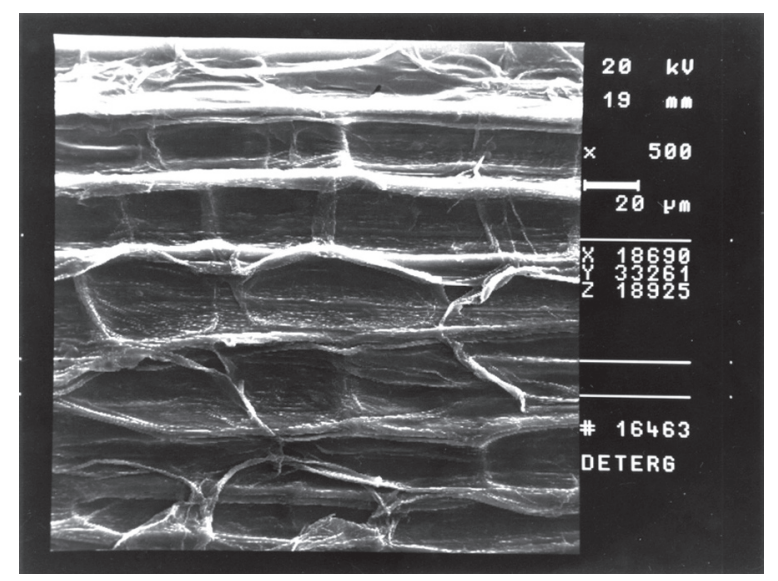

(b)

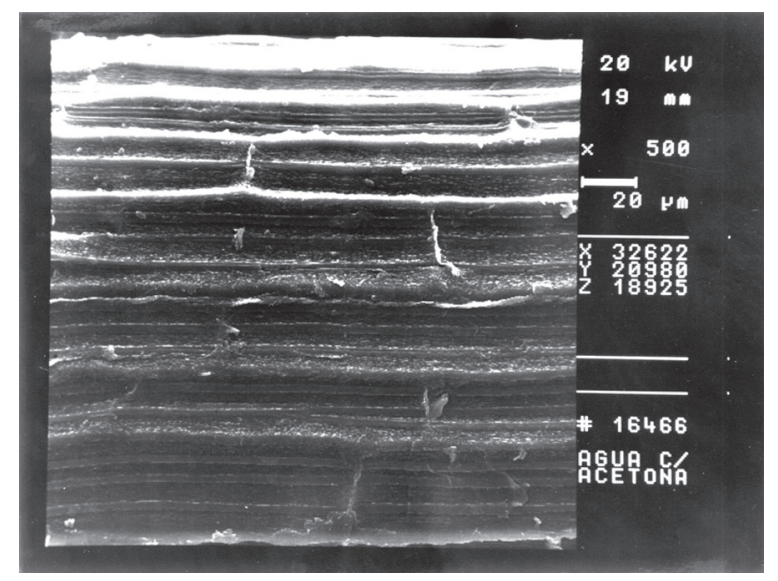

(c)

Figura 1. a) Micrografia obtida por MEV da superfície longitudinal de uma fibra de sisal sem tratamento; b) de uma fibra de sisal tratada com solução de detergente neutro a $20 \%$, durante 1 hora, $80^{\circ} \mathrm{C}$; e c) de uma fibra de sisal tratada com solução de água/acetona $(1: 1, \mathrm{v} / \mathrm{v})$, por 2 horas, temperatura ambiente. 500x.

com este tratamento foram as mesmas observadas após os tratamentos de lavagem com detergente e com solução água/ acetona.

A Figura 2 apresenta micrografias representativas do efeito do tratamento de mercerização na superfície da fibra. Observou-se o tratamento com $\mathrm{NaOH}$ remove os resíduos da 


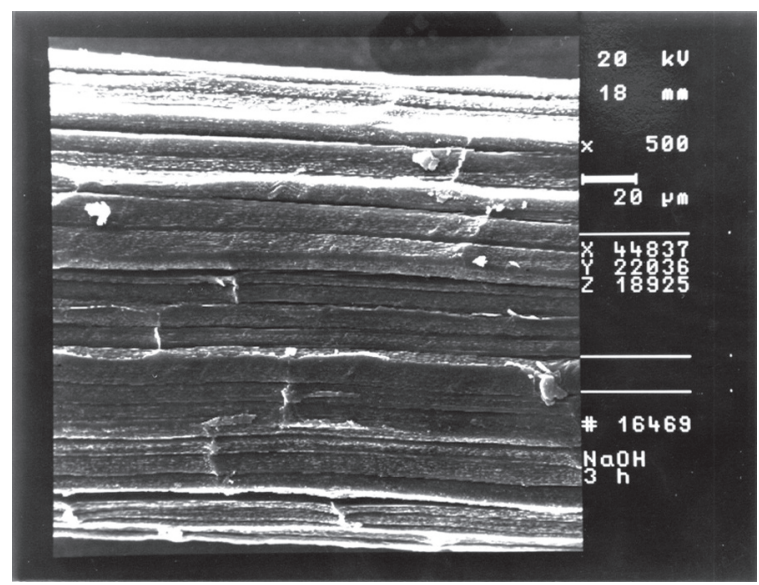

(a)

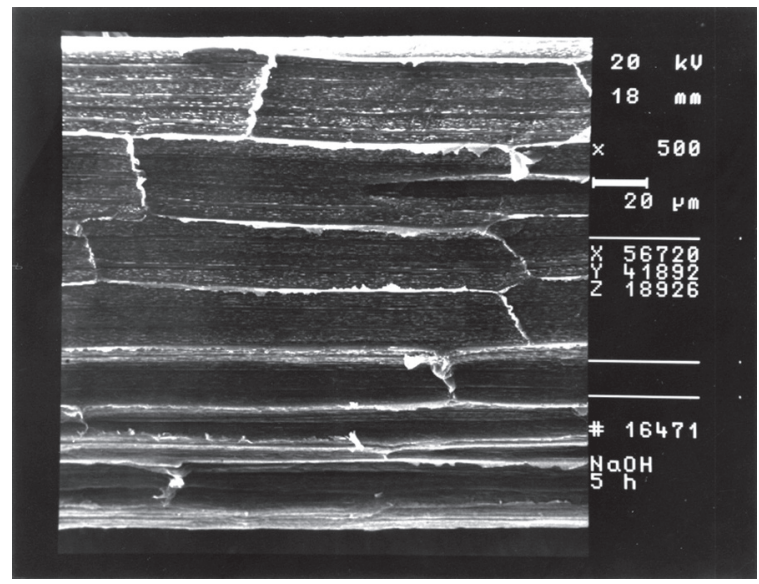

(b)

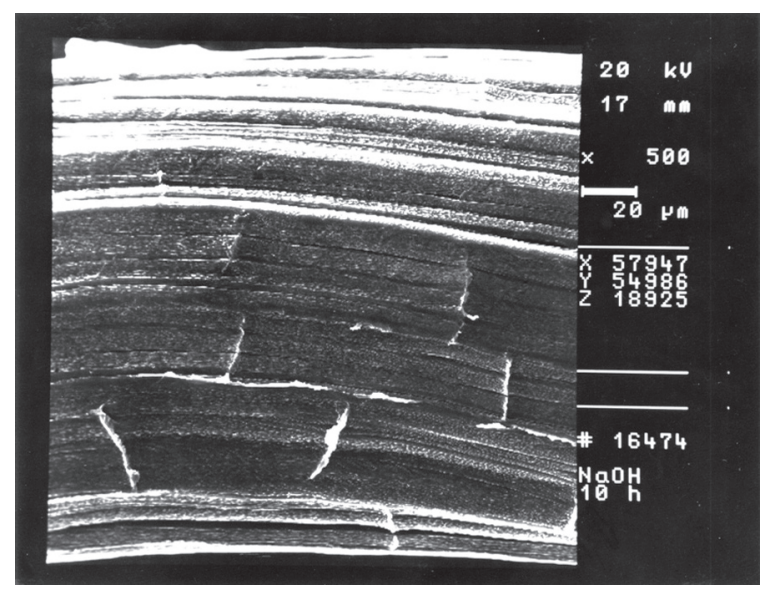

(c)

Figura 2. Micrografia obtida por MEV da superfície longitudinal de uma fibra de sisal mercerizada com solução de $\mathrm{NaOH}$ a $10 \%$, temperatura ambiente, durante a) 3 horas; b) 5 horas; e c) 10 horas. 500x.

superfície da fibra e parcialmente as células do parênquima. Observou-se também que as fibrilas que compõem a fibra ficaram mais expostas, o que leva a um aumento na área efetiva de contato entre a fibra e a matriz. Percebe-se ainda que os diferentes tempos de mercerização aplicados, não promoveram diferenças morfológicas significativas nas fibras, indicando que o tratamento mais adequado, por este aspecto, é para 3 horas de duração por ser o de menor custo.

Os resultados dos ensaios de resistência à tração da matriz e dos compósitos com e sem a adição de carbonato de cálcio, com as fibras sem tratamento, as lavadas com água, e as mercerizadas por 3 horas são apresentados na Figura 3. $\mathrm{O}$ teor de antioxidante e de fibra foi mantido constante em todos os casos em 1 pcr e 22 pcr, respectivamente. O teor de carbonato de cálcio de 33 e 67 pcr, e o comprimento das fibras, $6 \mathrm{~mm}$, foram estabelecidos em estudos anteriores ${ }^{[6]}$. Para a resistência à tração na ruptura, observou-se que existe uma tendência de aumento desta propriedade com o aumento do teor de carbonato de cálcio para os compósitos com fibra. Observou-se também que a adição de fibras reduziu esta propriedade e que os compósitos com fibras sem tratamento foram os que apresentaram o menor desempenho. $\mathrm{O}$ procedimento de lavagem das fibras elevou os valores de resistência à tração em relação aos obtidos com fibras sem tratamento, independentemente da matriz; e o uso de fibras mercerizada apresentou um efeito discretamente mais pronunciado, elevando a resistência à tração a patamares na faixa de $20 \%$ acima do encontrado com a fibra sem tratamento. Com relação ao módulo, vê-se que a adição de fibras aumentou esta propriedade e que o tratamento das fibras influenciou esta propriedade de forma similar ao da resistência à tração na ruptura; ou seja, os compósitos com as fibras mercerizadas apresentaram desempenho superior aos com fibras lavadas, e aqueles com fibras sem tratamento foram os com menor desempenho. Observou-se também que o teor de 33 pcr de carbonato eleva os valores de módulo a cerca de $100 \%$ em relação aos sem carbonato e que o aumento no teor de carbonato aumentou esta propriedade em todos os casos. Ou seja, percebe-se nitidamente que o uso combinado de carbonato de cálcio com fibras de sisal como reforço para a matriz de borracha nitrílica potencializa o módulo de elasticidade dos compósitos, levando a resultados superiores aos obtidos pelas contribuições individuais de cada uma das cargas (aumento de $220 \%$ em relação à borracha pura para o compósito onde o carbonato de cálcio e as fibras de sisal estão associados, em relação a $54 \%$ para a somatória das contribuições individuais de cada uma destas mesmas cargas). Os resultados para o alongamento na ruptura mostraram que, qualquer que seja o tipo de fibra empregada ocorre uma acentuada redução em todos os casos. Analisando-se isoladamente o comportamento para cada matriz (borracha pura, borracha com 33 pcr de carbonato e borracha com 67 pcr de carbonato) notou-se que os tratamentos não levaram a efeitos muito diferentes no grau de alongamento. Observouse também que o alongamento decresce ligeiramente quando o carbonato está associado ao compósito, sendo seu efeito mais pronunciado quando seu teor é mais elevado. No geral, as diferenças encontradas nos compósitos formados pelas fibras submetidas a distintos tratamentos, estão dentro do erro experimental. As melhores propriedades foram observadas para as composições com carbonato de cálcio. 


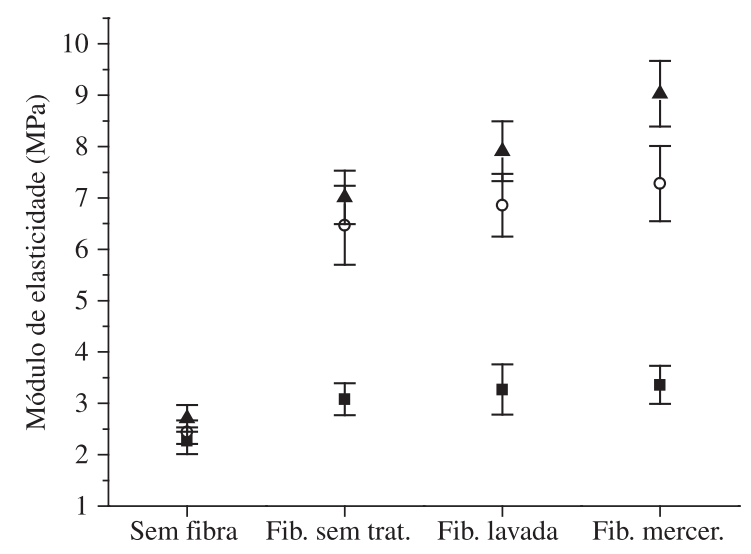

(a)

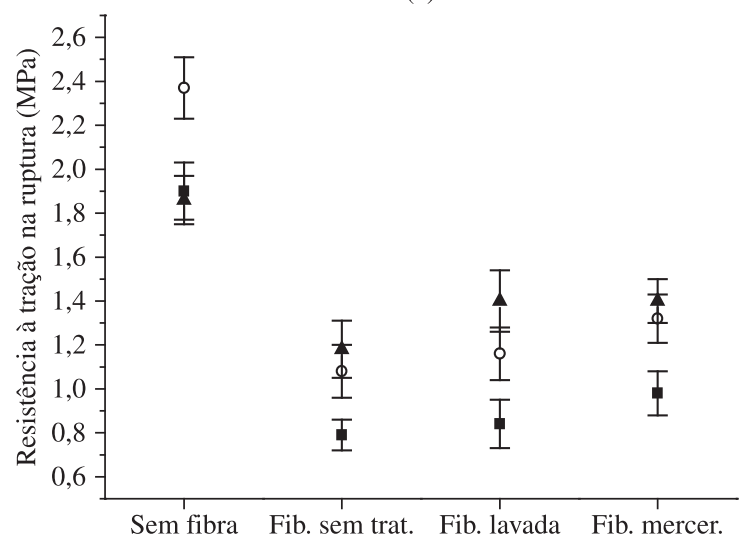

(b)

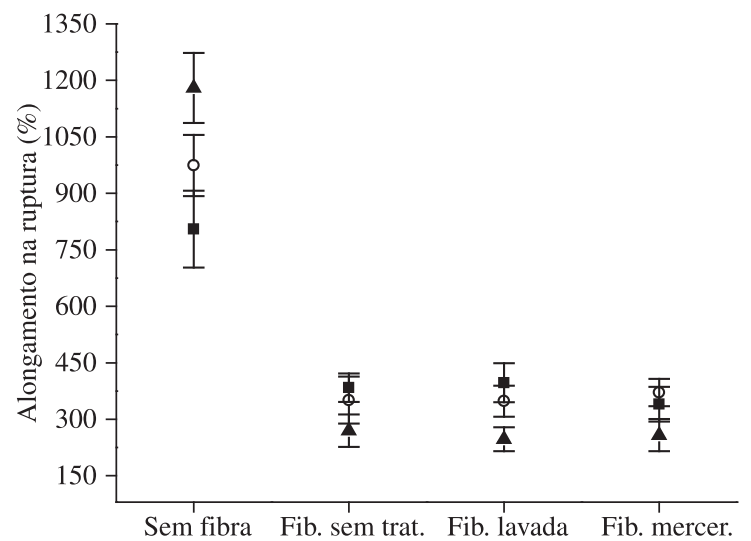

(c)

- Borracha nitrílica sem carbonato

- Borracha/33 pcr carbonato de cálcio

- Borracha/67 pcr carbonato de cálcio

Figura 3. Curvas de alongamento na ruptura (\%), resistência à tração na ruptura (MPa) e módulo de elasticidade a $10 \%$ de alongamento $(\mathrm{MPa})$, para o estudo da variação do tratamento da fibra de sisal, na borracha nitrílica; na borracha nitrílica com 33 pcr; e com 67 pcr de carbonato de cálcio. Teor de fibras de 22 pcr, com $6 \mathrm{~mm}$ de comprimento.

A partir dos resultados anteriores, o estudo da variação do teor de fibra nos compósitos com e sem a adição de carbonato de cálcio, Figura 4, foi realizado em compósitos com as fibras mercerizadas. Em relação ao módulo a $10 \%$, observou-se que nos compósitos com a matriz de borracha sem carbonato de cálcio esta propriedade pouco se altera à medida que

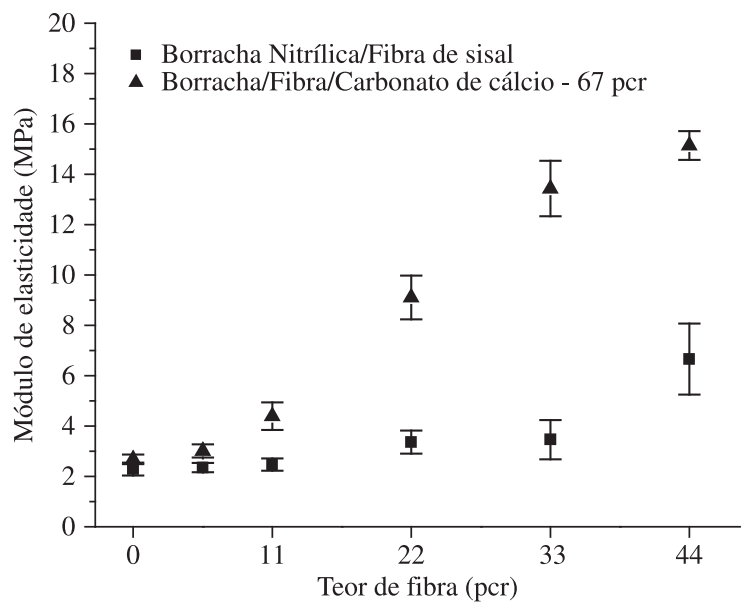

(a)

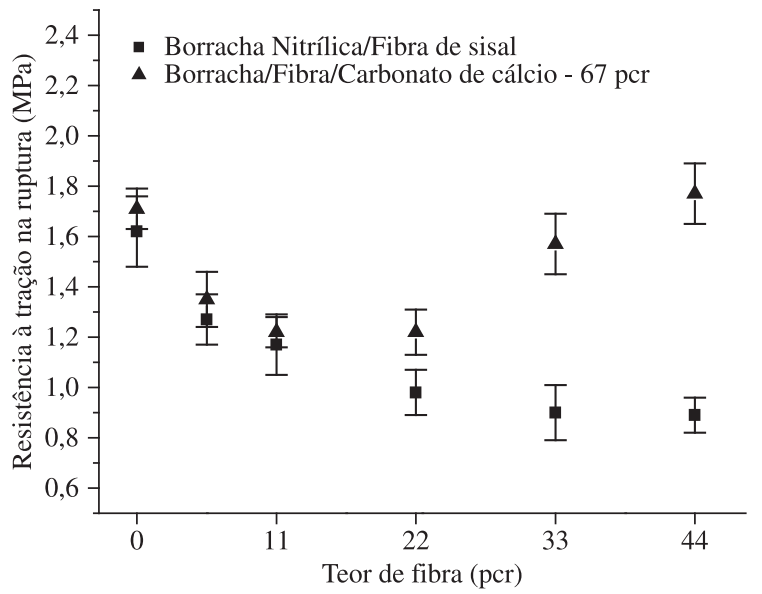

(b)

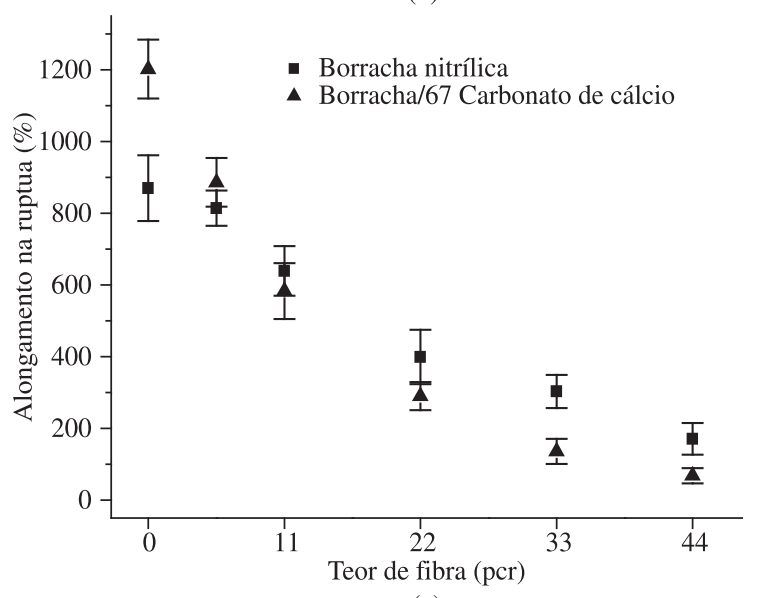

(c)

Figura 4. Curvas de alongamento na ruptura (\%), resistência à tração na ruptura (MPa) e módulo de elasticidade a 10\% de alongamento (MPa), para o estudo da variação do teor da fibra de sisal mercerizado $(\mathrm{NaOH} 10 \%$, 3 horas, temperatura ambiente), sobre borracha nitrílica pura e borracha nitrílica com 67 pcr de carbonato. Fibras com 6 mm de comprimento.

se aumenta o teor de fibras até 11 pcr. A partir de 11 pcr, verificou-se que o módulo tende a aumentar discretamente, apresentando um incremento elevado para o teor de 44 pcr de fibra. Já para a matriz de borracha com carbonato, o módulo aumenta com o aumento do teor de fibra a partir do teor de 
fibra de 5,5 pcr. Analisando as contribuições individuais e a combinação do carbonato de cálcio e fibras de sisal nesta propriedade, observou-se que para a combinação de um teor de 33 pcr de fibras mercerizadas com 67 pcr de carbonato, o módulo obtido foi de $13,43 \mathrm{MPa}$ (cerca de $485 \%$ superior ao encontrado para a borracha pura), que é superior à somatória das contribuições individuais, $51 \%$ proveniente da composição com carbonato, e $47 \%$ proveniente da combinação com fibras de sisal mercerizado; mostrando um efeito potencializado da combinação das cargas como reforço para o compósito.

A curva de resistência à tração na ruptura apresentou um comportamento oposto para os dois materiais. No caso da matriz de borracha sem carbonato de cálcio ocorreu um decaimento de desempenho com o aumento do teor de fibras, e na matriz de borracha com 67 pcr de carbonato observou-se que com a adição das fibras de sisal ocorreu um decréscimo até o teor de 11 pcr a partir do qual começa uma inversão na curva chegando a atingir, com o teor de 44 pcr, um valor de resistência à tração equivalente ao obtido para a matriz sem fibras. A adição de carbonato de cálcio influencia as propriedades dos materiais estudados, especialmente para valores mais elevados de fibra. Em compósitos reforçados com cargas particuladas, estas tendem a restringir o movimento da matriz na vizinhança de cada partícula. Essencialmente, a matriz transfere parte da tensão aplicada às partículas, as quais suportam uma fração da carga. No mecanismo das mudanças comportamento mecânico do material, basicamente, enquanto a matriz suporta a maior parte de uma carga que é aplicada, as partículas dispersas evitam ou dificultam a propagação de trincas $^{[22]}$. $\mathrm{O}$ efeito de cargas fibrosas na resistência à tração de ruptura de compósitos de borracha reforçados com fibras curtas tem sido amplamente estudado ${ }^{[2,6,9,12,21]}$. Geethamma e colaboradores ${ }^{[21]}$ relataram que geralmente a resistência à tração cai inicialmente até um teor de fibra a partir da qual passa a aumentar. Este volume mínimo de fibra é denominado como volume crítico, acima do qual a fibra reforça a matriz. $\mathrm{O}$ volume crítico varia com a natureza da fibra e da matriz, com a razão de aspecto da fibra, e com a adesão interfacial fibra/ matriz. No nosso trabalho, observou-se que para a matriz de borracha nitrílica na presença de carbonato de cálcio, o volume crítico para as fibras de sisal é de 11 pcr.

Com relação ao alongamento na ruptura observou-se que o aumento do teor de fibras de sisal levou a uma redução no alongamento dos compósitos, e também que a matriz com carbonato de cálcio apresentou uma queda mais acentuada nos valores de alongamento do que a observada para a matriz de borracha sem carbonato.

A Figura 5 mostra as curvas obtidas nas análises de TG para a borracha nitrílica, a borracha nitrílica com 67 pcr de carbonato de cálcio, os compósitos com a borracha nitrílica/22 pcr de fibras de sisal mercerizadas, e borracha/22 pcr fibras de sisal mercerizadas/67 pcr carbonato de cálcio. Observou-se que os compósitos que possuem fibras de sisal em sua composição apresentaram uma etapa a mais de decomposição, e que os compósitos com carbonato de

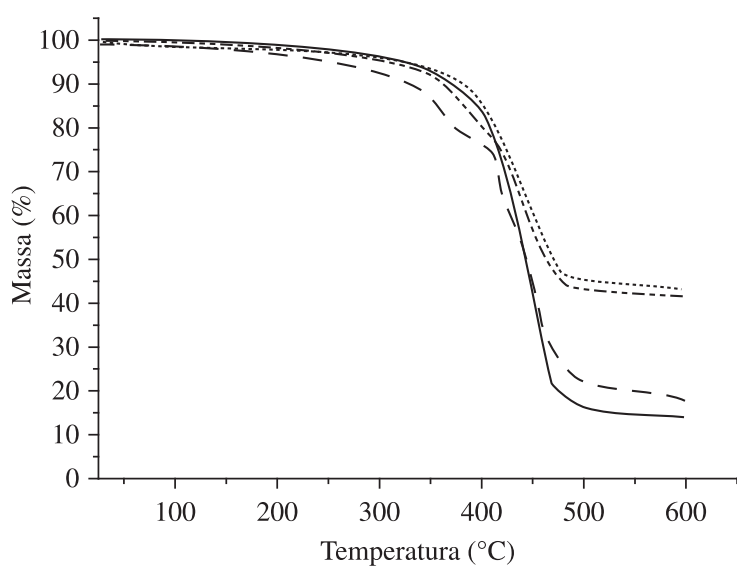

$$
\begin{aligned}
& \text { - Borracha Nitrílica } \\
& \text {----- Borracha/Carbonato de cálcio } \\
& \text { - - Borracha/Fibra de sisal } \\
& \text {---- Borracha/Carbonato/Fibra de sisal }
\end{aligned}
$$

Figura 5. Curvas de TG para borracha nitrílica, e compósitos de borracha/67 per de carbonato, borracha/22 per de fibra de sisal, e borracha/22 pcr fibra/67 pcr carbonato. Razão de aquecimento de $10{ }^{\circ} \mathrm{C} / \mathrm{min}$, fluxo de $\mathrm{N}_{2}$ de $15 \mathrm{~mL} / \mathrm{min}$.

cálcio apresentaram teores de resíduos bem mais elevados na temperatura final de $600{ }^{\circ} \mathrm{C}$. Observou-se ainda que todos os materiais estudados apresentaram boa estabilidade térmica até cerca de $300^{\circ} \mathrm{C}$, e que tanto a presença das fibras de sisal, quanto a do carbonato de cálcio não deslocam a temperatura final de decomposição (próximo a $480{ }^{\circ} \mathrm{C}$ ) das amostras. Até cerca de $350{ }^{\circ} \mathrm{C}$, a adição de carbonato de cálcio não influenciou de forma significativa a estabilidade térmica dos materiais obtidos, sendo que o processo de degradação observado a partir de $350{ }^{\circ} \mathrm{C}$ é devido a decomposição da borracha, das fibras e à hidrofilicidade do carbonato. $\mathrm{O}$ carbonato de cálcio comercial apresenta temperatura de início de decomposição em $600{ }^{\circ} \mathrm{C}$, liberando $\mathrm{CO}_{2}$ gerando $\mathrm{CaO}$ com conteúdo final de resíduo de cerca de $63 \%$, resultados semelhantes para compósitos com carbonato são relatados na literatura ${ }^{[23-25]}$. A partir dos resultados obtidos nas análises de TG vê-se que as temperaturas usadas nos tratamentos das fibras e na obtenção das mantas dos compósitos (máximo de $135^{\circ} \mathrm{C}$ ) são inferiores às temperaturas de degradação destes materiais, podendo ser usados para o seu processamento.

As curvas de DSC para a borracha nitrílica pura, a borracha nitrílica com 67 pcr de carbonato de cálcio, os compósitos com borracha nitrílica/22 pcr de fibras mercerizadas, e os com borracha nitrílica/22 pcr fibras mercerizadas/67 pcr carbonato de cálcio são apresentadas na Figura 6. Observou-se que todas as curvas apresentaram dois picos, um próximo a $-10{ }^{\circ} \mathrm{C}$ atribuído à transição vítrea da borracha nitrílica ${ }^{[26]}$, e outro exotérmico próximo a $365{ }^{\circ} \mathrm{C}$ atribuído à degradação da borracha nitrílica. Observou-se ainda que a presença das fibras de sisal e do carbonato de cálcio não levou a alterações significativas na temperatura de transição vítrea ou na temperatura de decomposição dos materiais, indicando que os materiais obtidos apresentam 


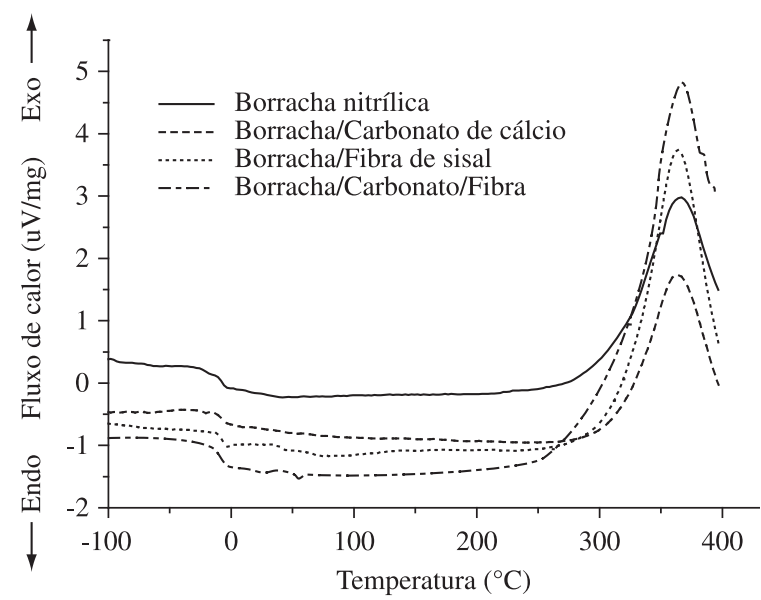

Figura 6. Curvas de DSC para borracha nitrílica, e compósitos de borracha/67 pcr de carbonato, borracha/22 pcr de fibra de sisal, e borracha/22 pcr fibra/67 pcr carbonato. Razão de aquecimento de $10{ }^{\circ} \mathrm{C} / \mathrm{min}$, fluxo de $\mathrm{N}_{2}$ de $30 \mathrm{~mL} / \mathrm{min}$.

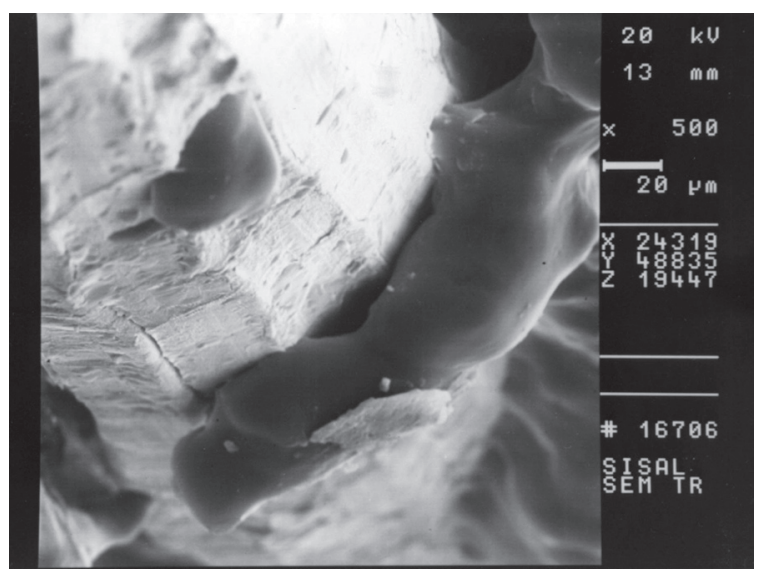

(a)

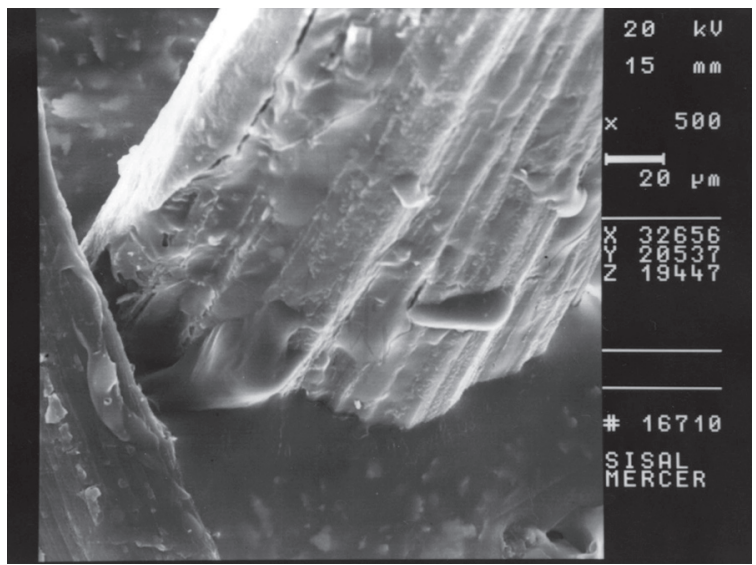

(b)

Figura 7. a) Micrografias representativas, obtidas por MEV, da superfície de fratura do compósito de borracha nitrílica com fibras de sisal sem tratamento; b) do compósito de borracha nitrílica com fibras de sisal mercerizadas. $500 \times$.

flexibilidade de cadeia e processo de degradação semelhante ao da matriz de borracha.

Com o objetivo de verificar a interação fibra/matriz realizou-se uma análise por MEV da superfície de fratura

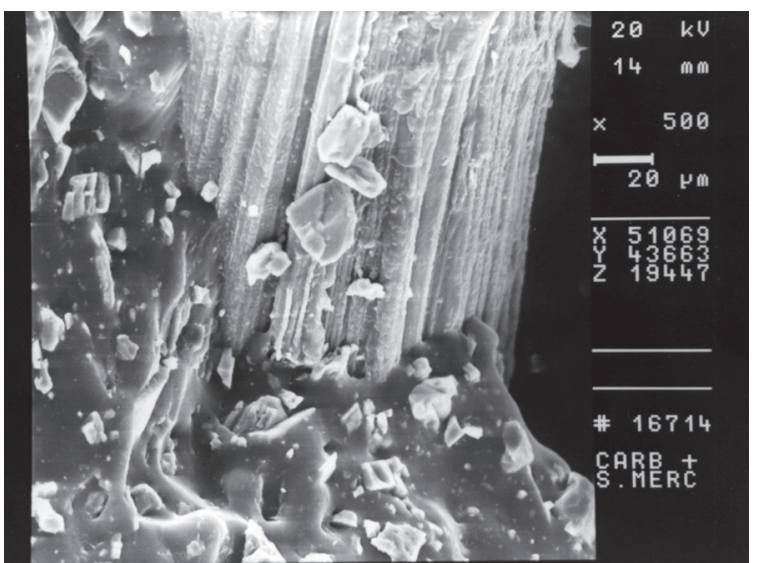

Figura 8. Micrografia representativa, obtida por MEV, da superfície de fratura de um compósito de borracha nitrílica/carbonato de cálcio/fibras de sisal mercerizadas. 500x.

dos compósitos, Figuras 7 e 8 . A partir da Figura 7 pode-se observar que a molhabilidade da fibra de sisal mercerizada na matriz de borracha é superior à apresentada pela fibra sem tratamento, onde podem ser observadas falhas na interface fibra/matriz. A Figura 8 apresenta a interface fibra/matriz para um compósito de borracha/fibra/carbonato de cálcio, vê-se que ocorre boa interação do carbonato com a matriz de borracha, e que este não influenciou na interação fibra/ matriz, indicando que para a borracha nitrílica, o carbonato não funciona apenas como uma carga para redução dos custos do compósito ${ }^{[5]}$, mas também como carga de reforço.

\section{Conclusões}

O tratamento de mercerização das fibras contribuiu para elevar as propriedades mecânicas dos compósitos de borracha nitrílica/fibra de sisal estudados. O uso combinado de $67 \mathrm{pcr}$ de carbonato com 33 pcr de fibras de sisal mercerizadas produziu um compósito com valor de módulo a $10 \%$ de alongamento cerca de $500 \%$ superior ao obtido para a borracha pura e sem perda da resistência à tração de ruptura. As fibras de sisal passaram a exercer uma ação de reforço na matriz de borracha nitrílica a partir do teor de 11 pcr. Para a matriz de borracha associada ao carbonato de cálcio este reforço se inicia com teores de fibra da ordem de 5,5 pcr. Os compósitos de borracha nitrílica com fibras de sisal e carbonato de cálcio são termicamente estáveis até cerca de $300{ }^{\circ} \mathrm{C}$ nas condições estudadas.

\section{Agradecimentos}

Os autores agradecem ao Dr. Odilon R.R.F. Silva da Embrapa/CNPA pelo fornecimento da fibra de sisal, ao CNPq e à FAPESP pelo apoio financeiro. 


\section{Referências Bibliográficas}

1. Ferreira, F. C.; Curvelo, A. A. S. \& Mattoso, L. H. C. Appl. Polym. Sci., 89, p.2957-2965 (2003).

2. Martins, M. A. \& Mattoso, L. H. C. - J. Appl. Polym. Sci., 91, p.670-677 (2004).

3. Joseph, K.; Medeiros, E. S. \& Carvalho, L. H. - Polímeros - Cienc Tecnol., 9, p.136-141 (1999).

4. Martins, G. S.; Martins, M. A.; Iozzi, M. A.; Ferreira, F. C. \& Mattoso, L. H. C. - Polímeros - Cienc Tecnol., 14, p.326-333 (2004).

5. Askeland, D. R. - "The Science and Engineering of Materials", PWS Publishing Company, Boston, p.527-572 (1994).

6. Iozzi, M. A.; Martins, M. A. \& Mattoso, L. H. C. Polímeros - Cienc Tecnol., 14, p.93-98 (2004).

7. Manroshan, S. \& Baharin, A. - J. Appl. Polym. Sci., 96, p.1550-1556 (2005).

8. Arayapranee, W. \& Rempel, G. L. - J. Appl. Polym. Sci., 110, p.1165-1174 (2008).

9. Cai, H.; Li, S.; Tian, G.; Wang, H. \& Wang, J. - J. Appl. Polym. Sci., 87, p.982-985 (2003).

10. Joseph, K. R.; Mattoso, L. H. C.; Toledo, R. D.; Thomas, S.; Carvalho, L. H.; Pothen, L.; Kala, S. \& James, B. - "Natural Fiber Reinforced Thermoplastic Composites", in: Natural Polymers and Agrofibers Based Composites, Frollini, E.; Leão, A.; Mattoso, L.H.C. (eds.), EMBRAPA, São Carlos, p.159-201 (2000).

11. Li, Y.; Mai, Y. \& Ye, L. - Compos. Sci. Technol., 60, p.2037-2055 (2000).

12. Martins, M. A. \& Joekes, I. - J. Appl. Polym. Sci., 89, p.2507-2515 (2003).

13. Mwaikambo, L. Y. \& Ansell, M. P. - Die Angew. Makromol. Chem., 272, p.108-116 (1999).
14. Zhang, W.; Zhang, X.; Liang, M. \& Lu, C. - Compos. Sci. Tecnhol., 68, p.2479-2484 (2008).

15. Tragoonwichian, S.; Yanurnet, N. \& Ishida, H. - J. Appl. Polym. Sci., 106, p.2925-2935 (2007).

16. Mattoso, L. H. C.; Ferreira, F. C. \& Curvelo, A. A. S. "Sisal Fiber: Morphology and Applications in Polymer Composites", in: Lignocellulosic-Plastic Composites, Leão, A. L.; Carvalho, F. X. \& Frollini, E. (eds.), São Paulo, USP, p.241-299 (1997).

17. Bledzki, A. K. \& Gassan, J. - Progr. Polym. Sci., 24, p.221-274 (1999).

18. Mukhopadhyay, S. \& Srikanta, R. - Polym. Deg. Stabil., 93, p.2048-2051 (2008).

19. Joseph, K.; Thomas, S. \& Pavithran, C. - Polymer, 37, p.5139-5149 (1996).

20. Joseph, K. \& Thomas, S. - J. Reinf. Plast Compos., 12, p.139-155 (1993).

21. Geethamma, V. G.; Mathew, K. T.; Lakshminarayanan R. \& Thomas, S. - Polymer, 39, p.1483-1491 (1998).

22. Callister Jr., W. D. - "Ciência e Engenharia de Materiais: uma introdução", LTC Editora, Rio de Janeiro (2002).

23. Huang, N. \& Wang, W. - J. Anal. Appl. Pyrolysis, 84, p.124-130 (2009).

24. Sant'Anna, S. S.; Souza, D. A.; Carvalho, C. F. \& Yoshida, M. I. - Ecl. Quím., 33, p.55-60 (2008).

25. Campos, J. S. C.; Ribeiro, A. A. \& Cardoso, C. X. Mater. Sci. Eng. B, 136, p.123-128 (2007).

26. Varghese, H.; Bhagawan, S. S.; Rao, S. S. \& Thomas, S. - Eur. Polym. J., 31, p.957-967 (1995).

Enviado: $15 / 04 / 09$

Reenviado: 10/11/09

Aceito: 19/11/09

DOI: $10.1590 / \mathrm{S} 0104-14282010005000003$ 